\title{
ОБОСНОВАНИЕ ТЕХНОЛОГИЧЕСКИХ ПАРАМЕТРОВ ТЕРМОМЕТРИЧЕСКОГО КОНТРОЛЯ СОСТОЯНИЯ ЛЕДОПОРОДНОГО ОГРАЖДЕНИЯ
}

\author{
Семин Михаил Александрович1, \\ seminma@outlook.com
}

Зайцев Артем Вячеславович1, aerolog.artem@gmail.com

\section{Паршаков Олег Сергеевич 1 ,} olegprashakov@gmail.com

\author{
Желнин Максим Сергеевич2, \\ zhelninmax@gmail.com \\ 1 Горный институт Уральского отделения Российской академии наук, \\ филиал Пермского федерального исследовательского центра Уральского отделения Российской академии наук, \\ Россия, 614007, г. Пермь, ул. Сибирская, 78-А. \\ 2 Институт механики сплошных сред Уральского отделения Российской академии наук, \\ филиал Пермского федерального исследовательского центра Уральского отделения Российской академии наук, \\ Россия, 614013, г. Пермь, ул. Академика Королева, 1.
}

\begin{abstract}
Актуальность исследования обусловлена отсутствием в нормативных документах, регламентирующих выполнение контроля за породным массивом в условиях его искусственного замораживания, единых требований к организации и осуществлению контроля за формированием и состоянием ледопородного ограждения.

Цель работы заключается в обосновании оптимальных технологических параметров термометрического контроля ледопородных ограждений строящихся шахтных стволов.

объектами исследования в настоящей работе являются замораживаемый породный массив и система искусственного замораживания.

Методы: экспериментальные исследования динамики температуры замораживаемых горных пород, статистическая обработка и анализ экспериментальных данных; математическое моделирование термодинамических процессов, происходящих 8 условиях искусственного замораживания породного массива.

Результаты. Приведены результаты обработки экспериментальных измерений температуры горных пород в контрольнотермических скважинах строящихся шахтных стволов способом искусственного замораживания. На основании обработки и анализа экспериментальных данных установлена закономерность влияния процесса искусственного замораживания на локальные участки породного массива. Проведено исследование влияния расположения контрольно-термической скважины на точность решения обратной задачи Стефана, позволяющей производить корректировку теплофизических свойств породного массива и рассчитывать температурное поле во всем объеме участка замораживаемого массива горных пород. Onределено, что термометрическую скважину следует размещать в замковой плоскости ледопородного ограждения в точке $c$ наименьшей температурой. На основе анализа аварийного выхода из строя замораживающих колонок найдено требуемое количество контрольно-термических скважин, которое позволяет обеспечить всесторонний контроль за состоянием ледопородного ограждения. При осуществлении термометрического контроля для установления достоверных параметров ледопородного ограждения и выполнения дальнейшего адекватного моделирования термодинамических процессов, происходящих в замораживаемом породном массиве, выполнено обоснование оптимального расположения и количества контрольнотермических скважин с необходимым пространственным разрешением измерений температуры горных пород по их глубине. По результатам проведенной работы разработана методика выбора технологических параметров способа термометрического контроля ледопородных ограждений шахтных стволов.
\end{abstract}

\section{Ключевые слова:}

Ледопородное ограждение, шахтный ствол, термометрический контроль, технологические параметры, контрольно-термическая скважина, экспериментальные измерения температуры, замораживающая скважина, задача Стефана.

\section{Введение}

Промышленное освоение месторождений, залегающих в сложных геологических и гидрогеологических условиях, тесно связано с искусственным замораживанием горных пород при строительстве вертикальных шахтных стволов [1]. Действующие на территории Российской Федерации и Республики Беларусь правила безопасности предъявляют ряд требований к проведению подземных выработок способом замораживания. В частности, за состоянием замороженного породного массива должен быть организован систематический контроль, при этом ведение горных работ в условия заморозки разрешается только после образования герметичного (замкнутого) ледопородного ограждения (ЛПО) требуемой толщины. Ледопородное ограждение шахтного ствола служит для восприятия горного и гидростатического давлений (рис. 1). 


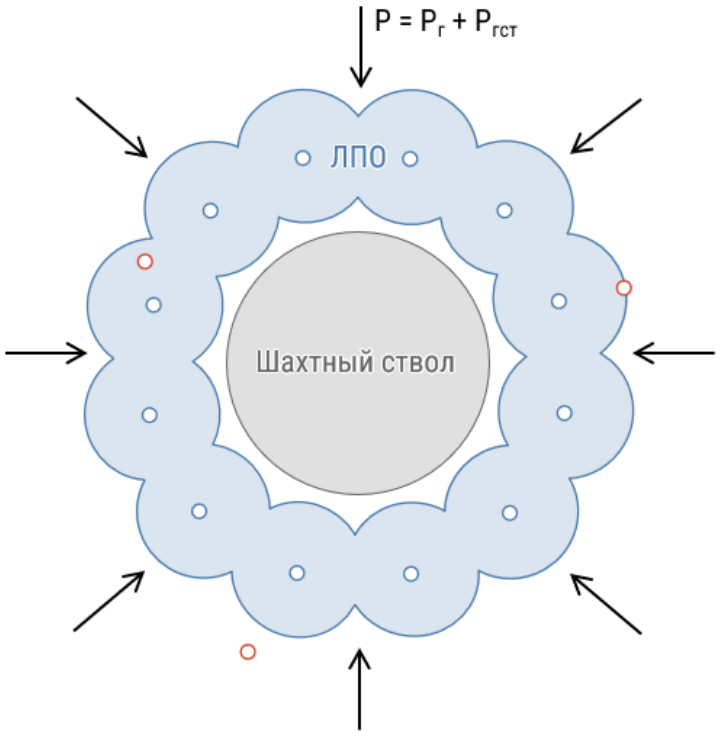

эмораживающая скважина о Контрольно-термическая скважина

Рис. 1. Упрощенное двухмерное представление ледопородного ограждения в плане

Fig. 1. Schematic $2 D$ representation of the frozen wall in horizontal plane

Одним из наиболее распространенных и информативных способов контроля параметров ледопородного ограждения шахтных стволов является термометрический. Термометрический способ контроля ЛПО заключается в осуществлении периодических измерений температуры горных пород в ограниченном количестве контрольно-термических скважин (как правило, бурится не более 3-4 скважин), расположенных на различных участках строительной площадки. Данные о распределении температуры в обводненном породном массиве позволяют судить о параметрах ледопородного ограждения - герметичности и толщине.

Точность и надежность определения фактического состояния ЛПО напрямую зависит от рационального выбора технологических параметров термометрического способа контроля, которые определяются до начала процесса замораживания горных пород. К технологическим параметрам относятся количество и расположение контрольно-термических скважин на промышленной площадке строящихся стволов, а также пространственное разрешение измерений температуры породного массива по глубине его замораживания.

Основы способа термометрического контроля преимущественно представлены в работе Н.Г. Трупака [2]. Автор указывает, что для представления хода процесса замораживания горных пород и суждения о состоянии ледопородного ограждения в тот или иной период его существования необходимо в первую очередь знать температуру пород в отдельных участках массива. Информация о температуре пород предоставляет возможность, с одной стороны, определить границы распространения теплоты, а следовательно, и контур ЛПО, а с другой стороны - прочность замороженной породы, находящуюся в прямой зависимости от понижения температуры. В работе представлены рекомендации по расположению и количеству контрольно-термических скважин, а также отмечена необходимость измерения температуры по всей глубине замораживания. Однако описанные технологические параметры термометрического контроля ледопородного ограждения не обоснованы и имеют только рекомендательный характер.

Следует отметить, что нормативные документы [3-8], регламентирующие выполнение контроля за породным массивом в условиях его искусственного замораживания, не предъявляют единых требований к организации и осуществлению контроля за формированием и состоянием ЛПО либо совсем не устанавливают их, а именно не изложены:

- требования к расположению контрольнотермических скважин и последовательности определения мест их заложения с учетом возможных отклонений фактических положений скважин от проектных и различия физических свойств обводненных горных пород;

- требования к оптимальному количеству контрольно-термических скважин, обеспечивающих получение достаточного объема информации о температуре горных пород в пределах участка строительства шахтных стволов;

- требования к техническим характеристикам термометрического оборудования (пространственное разрешение, точность и периодичность измерений).

На основании анализа можно сделать вывод, что в существующей литературе отсутствуют сведения по обоснованию технологических параметров способа термометрического контроля, кроме того, не предъявляются требования к организации и выполнению контроля за состоянием ледопородного ограждения шахтных стволов. В связи с чем для получения наиболее точных и полных данных о температуре замораживаемого породного массива, учитывая возможность применения ограниченного количества контрольно-термических скважин, необходимо провести исследование и выполнить обоснование оптимальных технологических параметров термометрического способа контроля ЛПО.

В результате для достижения поставленной цели в настоящей работе решаются следующие задачи:

1. Обработка и анализ экспериментальных измерений температуры горных пород в контрольнотермических скважинах шахтных стволов.

2. Исследование влияния расположения термометрической скважины на точность решения обратной задачи Стефана.

3. Анализ требуемого количества контрольнотермических скважин для выполнения всестороннего контроля параметров состояния ледопородного ограждения.

4. Определение необходимого пространственного разрешения распределенных измерений температуры массива пород по глубине термометрической скважины. 


\section{Экспериментальные измерения температуры горных пород}

Эффективность ледопородного ограждения главным образом зависит от его толщины, которая рассчитывается для каждого исследуемого слоя замораживаемого обводненного породного массива. Таким образом, основная задача термометрического контроля заключается в определении посредством контрольно-термических скважин положения границ ЛПО в массиве горных пород. Необоснованное расположение термометрических скважин затрудняет процедуру установления истинной толщины ледопородного ограждения, и, как следствие, приводит либо к более длительному процессу активного замораживания горных пород, либо, наоборот, к раннему переходу на пассивный режим заморозки.

В целях установления закономерности влияния искусственного замораживания на локальные участки породного массива выполнен анализ экспериментальных измерений температуры горных пород в контрольно-термических скважинах, расположенных на различных расстояниях от контура замораживающих скважин. Измерение температуры осуществлялось при помощи оптоволоконной технологии с использованием волоконно-оптического регистратора Ultima DTS производителя Silixa Ltd (Великобритания). Благодаря обработке и интерпретации обратного комбинационного рассеяния температура вдоль оптического волокна определялась с пространственным разрешением 25 см и с точностью измерения $0,1^{\circ} \mathrm{C}$.

Экспериментальные данные получены при помощи автоматизированной системы термометрического контроля, которая позволяет вывести на качественно новый уровень контроль формирования и состояния ледопородного ограждения строящихся шахтных стволов в сложных гидрогеологических условиях [9]. Отличительной особенностью системы контроля является возможность прогнозирования температурного поля во всем объеме участка породного массива на откалиброванной термодинамической модели породного массива. Калибровка параметров модели производится посредством численного решения обратной задачи Стефана с использованием данных экспериментальных измерений температуры горных пород в контрольно-термических скважинах [10]. Система контроля ЛПО реализована на строящихся рудниках Петриковского ГОК ОАО «Беларуськалий», Нежинского ГОК ИООО «Славкалий» и Талицкого ГОК उAO «BKК».

Принципиальная схема конструкции контрольнотермической скважины, включающая размещенный на всю глубину скважины оптоволоконный кабель, а также показательная динамика распределенной температуры замораживаемых горных пород, фиксируемая автоматизированной системой контроля, представлены на рис. 2.

В таблице приведены параметры некоторых исследуемых слоев горных пород замораживаемых участков породного массива, относящихся к различным горно-обогатительным комплексам, в которых авторами настоящей работы осуществлялся мониторинг температуры при проходке стволов. Параметры горных пород определены на основе результатов инженерно-геологических изысканий [11-15].

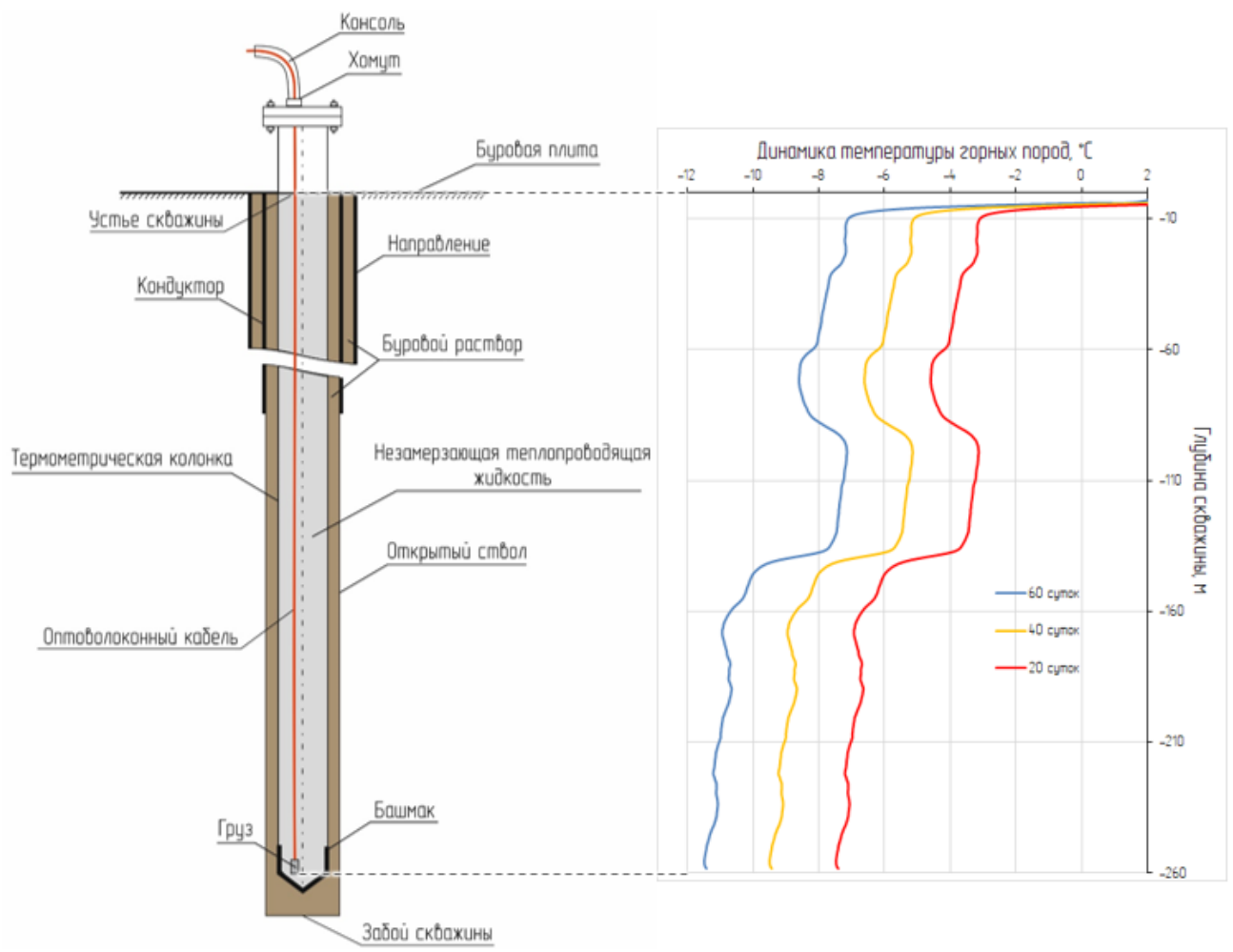

Рис. 2. Принципиальная схема конструкиии контрольно-термической скважины и показательная динамика температуры пород

Fig. 2. Design of the thermal control well and the time-dependent distribution of rock temperature in depth 
Таблица. Параметры исследуемых слоев породного массива

Table. $\quad$ Parameters of the studied layers of the rock mass

\begin{tabular}{|c|c|c|c|c|c|c|}
\hline \multirow{2}{*}{$\begin{array}{c}\text { Горно-обогатительный } \\
\text { комплекс } \\
\text { Mining and Processing } \\
\text { Plant }\end{array}$} & \multirow{2}{*}{$\begin{array}{c}\text { Слой } \\
\text { породы } \\
\text { Rock layer }\end{array}$} & \multirow{2}{*}{$\begin{array}{c}\text { Интервал } \\
\text { залегания, } \\
\text { м } \\
\text { Interval, m }\end{array}$} & \multicolumn{2}{|c|}{$\begin{array}{c}\text { Температуропроводность, } \mathrm{m}^{2} / \mathrm{c} \\
\text { Thermal diffusivity, } \mathrm{m}^{2} / \mathrm{s} \\
\end{array}$} & \multirow{2}{*}{$\begin{array}{c}\text { Влагосодер- } \\
\text { жание, кг/кг } \\
\text { Moisture } \\
\text { content, } \mathrm{kg} / \mathrm{kg} \\
\end{array}$} & \multirow{2}{*}{$\begin{array}{l}\text { Проектная толщи- } \\
\text { на ЛПО, } \text { M }^{*} \\
\text { Frozen wall design } \\
\text { thickness, } \mathrm{m}^{*} \\
\end{array}$} \\
\hline & & & $\begin{array}{l}\text { в зоне льда } \\
\text { frozen zone }\end{array}$ & $\begin{array}{l}\text { в зоне охлаждения } \\
\text { unfrozen zone }\end{array}$ & & \\
\hline $\begin{array}{c}\text { Нежинский } \\
\text { Nezhinskiy }\end{array}$ & $\begin{array}{l}\text { Глина } \\
\text { Clay }\end{array}$ & $119 \ldots 147$ & $1,21 \cdot 10^{-6}$ & $8,38 \cdot 10^{-7}$ & 0,36 & 3,79 \\
\hline \multirow{2}{*}{$\begin{array}{l}\text { Петриковский } \\
\text { Petrikovskiy }\end{array}$} & $\begin{array}{c}\text { Мел } \\
\text { Chalk } \\
\end{array}$ & $85 \ldots 136$ & $8,1 \cdot 10^{-7}$ & $4,0 \cdot 10^{-7}$ & 0,26 & 1,85 \\
\hline & $\begin{array}{l}\text { Песчаник } \\
\text { Sandstone }\end{array}$ & $136 \ldots 146$ & $1,47 \cdot 10^{-6}$ & $8,14 \cdot 10^{-7}$ & 0,17 & 2,50 \\
\hline $\begin{array}{l}\text { Талицкий } \\
\text { Talitskiy }\end{array}$ & $\begin{array}{c}\text { Mергель } \\
\text { Mergel }\end{array}$ & $159 \ldots 187$ & $1,57 \cdot 10^{-6}$ & $9,52 \cdot 10^{-7}$ & 0,13 & 6,34 \\
\hline
\end{tabular}

* - проектная толщина ледопородного ограждения в исследуемых слоях глины и песчаника рассчитана для температуры замороженной горной породы $-8{ }^{\circ} \mathrm{C}$, в слое мергеля для температуры $-10{ }^{\circ} \mathrm{C}$.

* - the design thicknesses of the frozen wall in clay and sandstone layers are calculated for a temperature -8 ${ }^{\circ} \mathrm{C}$, the design thickness in a mergel layer is calculated for temperature $-10^{\circ} \mathrm{C}$.

Из таблицы видно, как существенно может варьироваться требуемая толщина ледопородного ограждения для разных слоев замораживаемых участков породного массива. Необходимо отметить, что ниже будут приведены результаты обработки экспериментальных данных по термометрии только для слоя глины.
На рис. 3 представлена динамика температуры слоя глины в контрольно-термических скважинах ствола № 1 Нежинского ГОК и фактическое положение границ ЛПО на момент (90 суток после начала замораживания) достижения им проектных параметров.

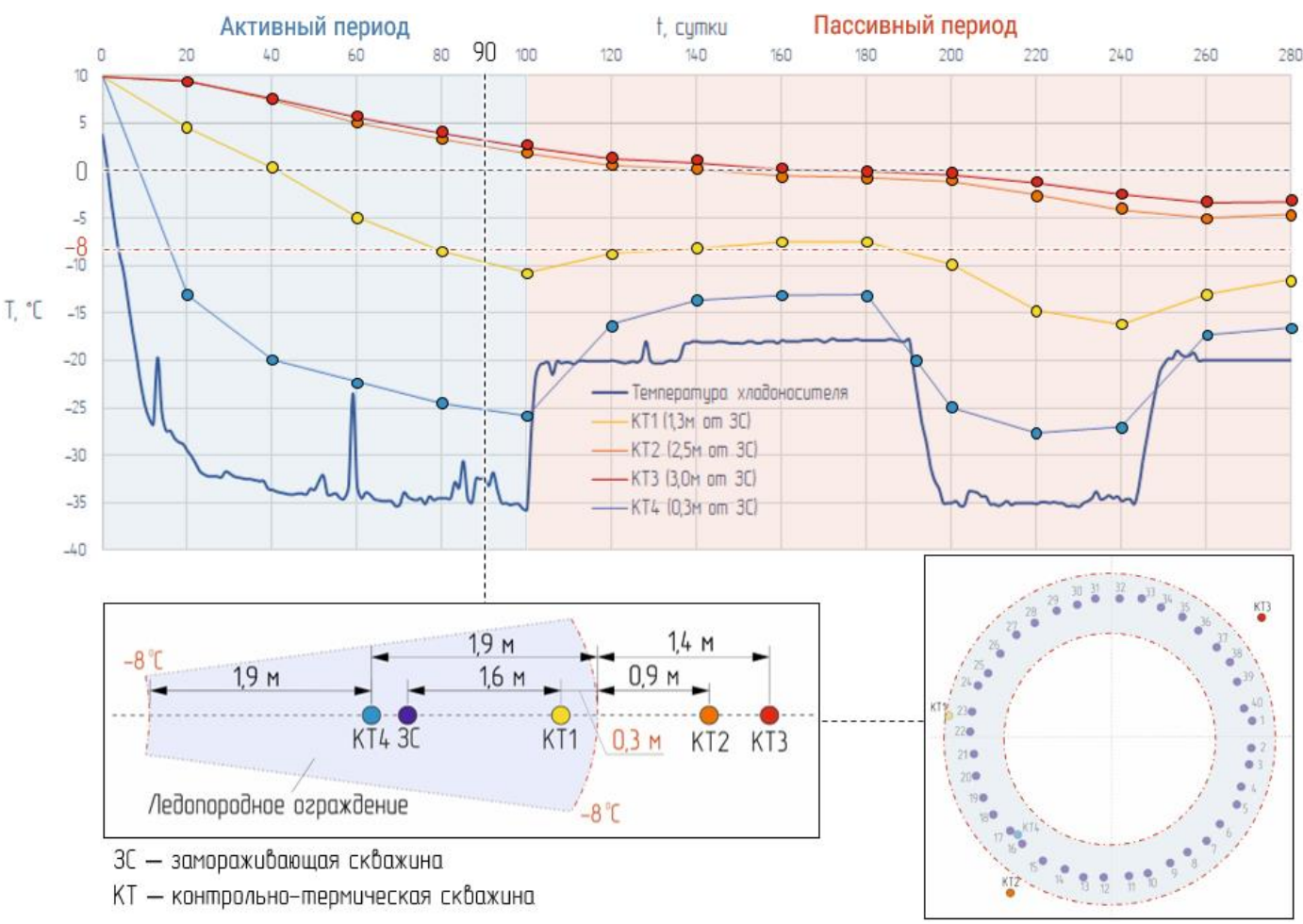

Pис. 3. Динамика температуры слоя глины в контрольно-термических скважинах и фактическое положение гранич ледопородного ограждения на момент достижения им проектных параметров

Fig. 3. Dynamics of the clay layer temperature in the control wells and the actual position of the frozen wall boundaries at the time it reaches design parameters

На основании полученных экспериментальных данных установлено, что графики температуры в контрольно-термических скважинах, расположенных в пределах проектной толщины ЛПО (в зоне льда), качественно повторяют график температуры прямого потока хладоносителя, циркулирующего в замораживающих скважинах. На удалении от внешней границы ледопородного огражде- ния температура в термометрических скважинах, расположенных в зоне охлаждения, длительное время (до 250 суток) после начала замораживания горных пород продолжала понижаться независимо от изменения температуры хладоносителя. Отмечается, что в других исследуемых слоях замораживаемых горных пород, слагающих породный массив, наблюдаются аналогичные процессы. 
Кроме этого, из рис. 3 следует, что на момент достижения ЛПО (90 суток после начала замораживания) требуемой толщины ближайшая к его внешней границе контрольно-термическая скважина расположена на расстоянии 0,3 м. Это связано с тем, что при выборе места заложения контрольно-термических скважин не учитываются их отклонения от вертикали и отклонения замораживающих скважин. Также зачастую не принимается во внимание неравномерность распространения замороженной зоны от контура замораживающих скважин. Опыт показывает, что замороженная зона распространяется примерно в соотношении $60 \%$ в направлении к оси шахтного ствола и $40 \%$ в направлении от нее $[1,2]$.

Следовательно, экспериментальные исследования показывают, что выбор мест заложения контрольнотермических скважин на промышленной площадке строительства шахтных стволов обуславливается проектными параметрами ледопородного ограждения координатами замораживающих скважин и необходимостью получения данных о температуре породного массива на различных его участках относительно контура замораживающих скважин.

\section{Исследование влияния расположения}

\section{термометрической скважины}

\section{на точность решения обратной задачи Стефана}

Базовой математической моделью для описания распределения температуры в среде с учетом фазового перехода является модель теплопереноса в обводненном породном массиве с движущейся границей фазового перехода, а соответствующая задача называется прямой задачей Стефана [16-20]. При калибровке параметров тепловой модели массива используются данные экспериментальных измерений температуры пород в контрольно-термических скважинах. Математически это приводит к переопределению прямой задачи Стефана и необходимости решать коэффициентную обратную задачу Стефана [21].

Известно, что при идентификации параметров среды, участвующей в нестационарном теплообмене, посредством решения некорректных и обратных задач адекватность восстанавливаемых теплофизических характеристик реальным величинам во многом определяется условиями проведения эксперимента [22-27]. Поэтому для повышения точности и надежности решений, получаемых в результате решения обратной задачи Стефана, важно оптимальным образом спланировать эксперимент, найти оптимальный план. В широком смысле планирование экспериментальных измерений температуры подразумевает определение количества и мест заложения контрольных скважин, выбор измерительной аппаратуры, выбор методов обработки собираемых данных, методов калибровки измерительной аппаратуры посредством сравнения с эталонными датчиками и пр. В настоящей работе рассматривается вопрос выбора количества и мест заложения контрольных скважин, при котором корректировка теплофизических свойств породного массива будет проводиться с наибольшей точностью [28-30].
Рассматривается горизонтальный разрез породного массива и система замораживающих скважин. В силу симметрии задачи можно рассмотреть только часть массива, находящуюся между двумя главными плоскостями ледопородного ограждения, проведенными через соседние замораживающие скважины. Геометрия расчетной области $\Omega$ представлена на рис. 4.

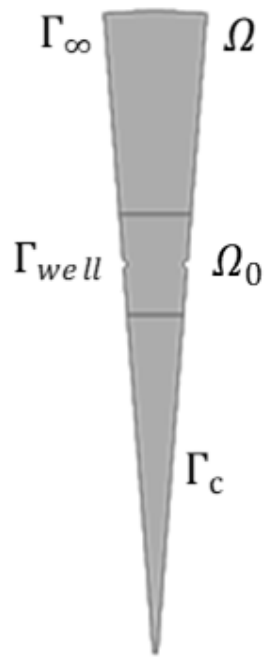

Puc. 4. Геометрия расчетной области: $\Omega . \Omega_{0}-$ область, заключенная между двумя горизонтальными линиями, $\Gamma_{\text {well }}$ - граница замораживающей скважины, $\Gamma_{\infty}-$ внешняя граница расчетной области, $\Gamma_{\mathrm{c}}=\partial \Omega \backslash\left(\Gamma_{\text {well }} \cup \Gamma_{\infty}\right)$

Fig. 4. Geometry of the computational domain: $\Omega . \Omega_{0}-$ the area enclosed between two horizontal lines, $\Gamma_{\text {well }}-$ the boundary of the freezing well, $\Gamma_{\infty}$ - the external boundary of the calculation domain, $\Gamma_{\mathrm{c}}=\partial \Omega \backslash\left(\Gamma_{w e l l} \cup \Gamma_{\infty}\right)$

Задается множество точек $\xi$ - кандидатов на место расположения термометрической скважины.

$$
\xi=\left\{\left(x_{1}, y_{1}\right), \ldots,\left(x_{N}, y_{N}\right)\right\} .
$$

Здесь $N$ - общее количество возможных точек расположения контрольно-термической скважины.

Также задается набор параметров термодинамической модели (или теплофизических свойств ва) $\Theta=\left\{\theta_{1}, \ldots, \theta_{m}\right\}$, которые требуется определить в ходе решения обратной задачи Стефана максимально достоверно и для определения которых разрабатывается оптимальный план эксперимента, ищется оптимальное расположение контрольно-термической скважины.

Поиск оптимального плана в настоящей работе осуществлялся с помощью информационной матрицы Фишера [26], которая имеет следующий вид:

$$
\mathbf{F}\left(\xi, t_{\mathrm{K}}\right)=\frac{1}{N\left(t_{\mathrm{K}}-t_{0}\right)} \int_{t_{0}}^{t_{\mathrm{K}}} \mathbf{S}(\Theta, \xi)^{T} \mathbf{S}(\Theta, \xi) \mathrm{d} t,
$$

где $t_{0}$ - начальный момент времени, с; $t_{k}-$ конечный момент времени, с; $\mathbf{S}(\Theta)$ - матрица чувствительности, которая для общего случая идентификации $m$ параметров $\Theta=\left\{\theta_{1}, \ldots, \theta_{m}\right\}$ при решении обратной задачи, имеет вид: 


$$
\mathbf{S}(\Theta)=\left(\begin{array}{ccc}
\left.\frac{\partial T}{\partial \theta_{1}}\right|_{\left(x_{1}, y_{1}\right)} & \ldots & \left.\frac{\partial T}{\partial \theta_{m}}\right|_{\left(x_{1}, y_{1}\right)} \\
\vdots & \ddots & \vdots \\
\left.\frac{\partial T}{\partial \theta_{1}}\right|_{\left(x_{N}, y_{N}\right)} & \ldots & \left.\frac{\partial T}{\partial \theta_{m}}\right|_{\left(x_{N}, y_{N}\right)}
\end{array}\right) .
$$

Компоненты матрицы $\mathbf{S}(\Theta)$ - частные производные температуры по каждому из искомых теплофизических параметров $\theta_{i}$ в каждой точке из множества (1) точек-кандидатов на месторасположение термометрической скважины. Наибольшие значения компонент в каждом ј-м столбце матрицы (3) соответствуют тем точкам, в которых влияние параметра $\theta_{j}$ на решение проявляется наиболее сильно в данный момент времени.

Переход от матрицы чувствительности $\boldsymbol{S}(\Theta, \xi)$ к матрице Фишера $\mathbf{F}\left(\xi, t_{\mathrm{K}}\right)$ с помощью преобразования (2) делается для того, чтобы учесть при анализе временной фактор. То есть найти такие точки $\xi_{i}$, в которых влияние параметра $\theta_{j}$ на поле температур проявляется наиболее сильно для всего рассматриваемого временного промежутка $\left[t_{0}, t_{\mathrm{K}}\right]$.

Далее для решения оптимизационной задачи вводится следующий скалярный критерий оптимальности экспериментального плана (D-критерий) [26]:

$$
\Phi\left(\xi, t_{\mathrm{K}}\right)=-\ln \operatorname{det} \mathbf{F}\left(\xi, \mathrm{t}_{\mathrm{K}}\right), \xi \subset \Xi,
$$

где det - операция взятия определителя матрицы.

Оптимальный план $\xi^{*}$ эксперимента находится из решения задачи минимизации функции $\Phi$. В данной работе для поиска минимума функции $Ф$ использует- ся метод сопряженных градиентов. Для простоты в работе рассматривается случай, когда обратная задача Стефана сформулирована относительно одного неизвестного теплофизического параметра $\lambda_{s d}$ - теплопроводности в зоне льда.

Решение задачи оптимального планирования выполнено для условий исследуемых слоев горных пород рудника Петриковского ГОК - для наиболее (песчаник кварцевый) и наименее (мел) теплопроводных. Результаты решения задачи оптимального планирования эксперимента по определению одной контрольно-термической скважины представлены для слоя мела.

Геометрические параметры расчетной области: радиус кругового сектора $R=16,25$ м, угол сектора $\alpha=2 \pi / 41$, радиус замораживающей скважины $R_{\text {well }}=0,073$ м, расстояние от центра кругового сектора до центра замораживающей скважины (или радиус контура замораживания) $R_{c}=8,25 \mathrm{M}$.

Теплофизические параметры задачи: начальная температура породного массива и температура на внешней границе области $T=7^{\circ} \mathrm{C}$. Удельная теплота кристаллизации $\mathrm{L}=3,3 \cdot 10^{5}$ Дж/кг, температура фазового перехода $T_{p h}=0^{\circ} \mathrm{C}$. Основные теплофизические свойства песчаника кварцевого и мела приведены в таблице.

На рис. 5 представлены распределения функции $\Phi$ в рассматриваемой области породного массива для слоя мела при различных временах $t_{\mathrm{K}}$ и график функции Ф в зависимости от $t$ в точках $\left(x_{i}, y_{i}\right)$.
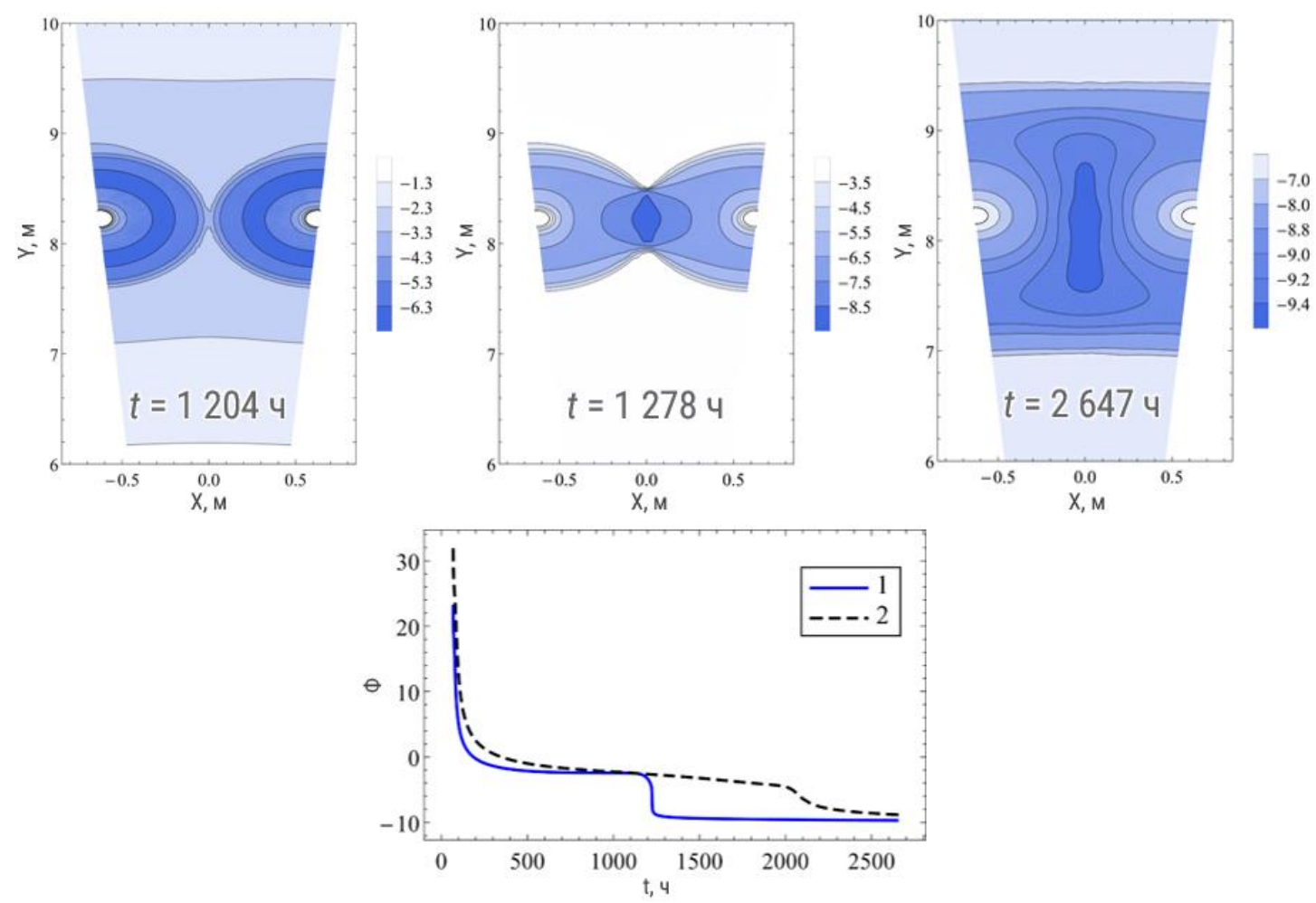

Puc. 5. Распределение D-критерия Ф в области $\Omega_{0}$ и график функиии Ф от времени $t: 1$ - в точке $\left(x_{1}, y_{1}\right)=(0,0 ; 8,22)$, 2 - в точке $\left(x_{2}, y_{2}\right)=(0,0 ; 9,25)$

Fig. 5. Distribution of the $D$-criterion $\Phi$ in the domain $\Omega_{0}$ and a the function $\Phi$ versus time $t$ : 1 - at the point $\left(x_{1}, y_{1}\right)=(0,0 ; 8,22)$, 2 - at the point $\left(x_{2}, y_{2}\right)=(0,0 ; 9,25)$ 
В момент времени $t_{\mathrm{\kappa}}=t_{\min , p h}=1204$ ч происходит смыкание границ фазового перехода, минимумы функции Ф расположены на кривых, находящихся в двух областях вблизи замораживающих скважин. На графиках для моментов времени $t_{\mathrm{K}}=t_{\min , \text { infl }}=1278$ ч и $t_{\mathrm{K}}=t_{\min , p r}=2647$ ч, где $t_{\min , i n f l}-$ момент времени после резкого убывания графика $\Phi, t_{\min , p r}-$ время достижения ЛПО проектной толщины, минимум функции $\Phi$ расположен в замковой плоскости на прямой, проходящей посредине между замораживающими скважинами.

Путем решения задачи минимизации (4) для различных времен $t_{\mathrm{K}}$ из промежутка $t_{\min , i n f l}$ до $t_{\min , p r} \mathrm{c}$ шагом 342,25 ч установлено, что во всех случаях точка минимума функции $\Phi$ совпадает с точкой $(0,0$; $8,22)$, имеющей наименьшую температуру. Исходя из этого можно сделать вывод, что в исследуемом слое мела для решения обратной задачи с наибольшей точностью на момент достижения ЛПО проектной толщины контрольно-термическую скважину следует размещать в точке с минимальной температурой - на прямой, проходящей посредине между замораживающими скважинами.

В работе также получено решение задачи об оптимальном расположении контрольной скважины для слоя песчаника кварцевого. Установлено, что точка минимума функции $Ф$ практически совпадает со случаем слоя мела. Это указывает на то, что оптимальные координаты скважины, скорее всего, не зависят от теплофизических параметров горной породы. Следует отметить, что здесь рассматривался случай, когда в ходе решения обратной задачи требуется определить только один модельный параметр - теплопроводность в зоне льда. При рассмотрении обратных задач с определением других теплофизических свойств задачи положение минимума $\Phi$ может измениться.

\section{Анализ требуемого количества контрольно-термических скважин для выполнения всестороннего контроля параметров ледопородного ограждения}

Рассчитываемые параметры ледопородного ограждения напрямую зависят от количества контрольно-термических скважин, используемых для осуществления контроля за тепловым полем участка замораживаемого породного массива вокруг строящихся шахтных стволов. Существует множество исследований, посвященных вопросам контроля состояния ЛПО [31-36]. Однако вопрос о требуемом количестве термометрических скважин, которое позволит обеспечить получение информации о состоянии ледопородного ограждения в полном объеме (по всему замораживаемому контуру), а следовательно, и безопасность ведения горных работ при проходке ствола, остается нерешенным.

При определении оптимального количества термометрических скважин следует учитывать два основных фактора:

1) повышение безопасности за счет получения наиболее полной информации о температуре гор- ных пород на всем участке замораживаемого породного массива с учетом возможности раннего предупреждения аварийной ситуации при выходе из работы замораживающих колонок или наличии в породном массиве локальных неоднородностей;

2) обеспечение минимальных сроков и затрат на бурение, а также обустройство контрольнотермических скважин.

Данные факторы находятся в разногласии между собой, так как чем больше количество контрольнотермических скважин, тем более достоверное представление о параметрах состояния ледопородного ограждения во всем объеме замораживаемого породного массива, а значит, и большая вероятность раннего предотвращения аварии, но с другой стороны, тем более высокие затраты на производство работ по бурению и обустройству скважин, и наоборот. Как правило, в целях экономии финансовых и трудовых ресурсов предпочтение отдается второму фактору, в связи с чем количество контрольно-термических скважин при искусственном замораживании горных пород зачастую не превышает 3-4 скважин при общем количестве замораживающих скважин более 40. При этом задача по нахождению максимального количества термометрических скважин, обеспечивающих всесторонний контроль параметров ледопородного ограждения и исключение аварийных ситуаций, связанных с выходом из строя замораживающих колонок, прежде не рассматривалась.

По данной причине выполнено многовариантное численное моделирование теплопереноса в замораживаемом породном массиве, в процессе которого исследовалось влияние поломки двух смежных замораживающих колонок на распределение температуры в слое горной породы. Выбор двух, а не одной замораживающей колонки сделан для того, чтобы добиться ситуации, когда в окрестности неисправных колонок после их выхода из строя толщина ЛПО не увеличивалась в течение длительного времени (более 100 суток). В качестве критерия $K$, позволяющего оценить влияние поломки скважин, выступало рассогласование температур:

$$
K=T_{1}-T_{2},
$$

где $T_{1}$ - температура породного массива при учете выхода из строя двух соседних замораживающих колонок, ${ }^{\circ} \mathrm{C} ; \mathrm{T}_{2}$ - температура породного массива без учета выхода из строя двух соседних замораживающих колонок, ${ }^{\circ} \mathrm{C}$.

Рассмотрен случай, при котором спустя 5 суток после начала замораживания наиболее теплопроводного слоя горной породы выходят из строя две смежные колонки. Случай соответствует неблагоприятному развитию событий, при котором в начальный период замораживания теплопритоки являются максимальными.

Распределение температуры спустя 5 суток после начала замораживания слоя породы при нормальной работе всех замораживающих колонок и рассогласование температур (5) без и с отключением двух смежных замораживающих колонок через сутки, 15 и 25 суток представлены на рис. 7. 

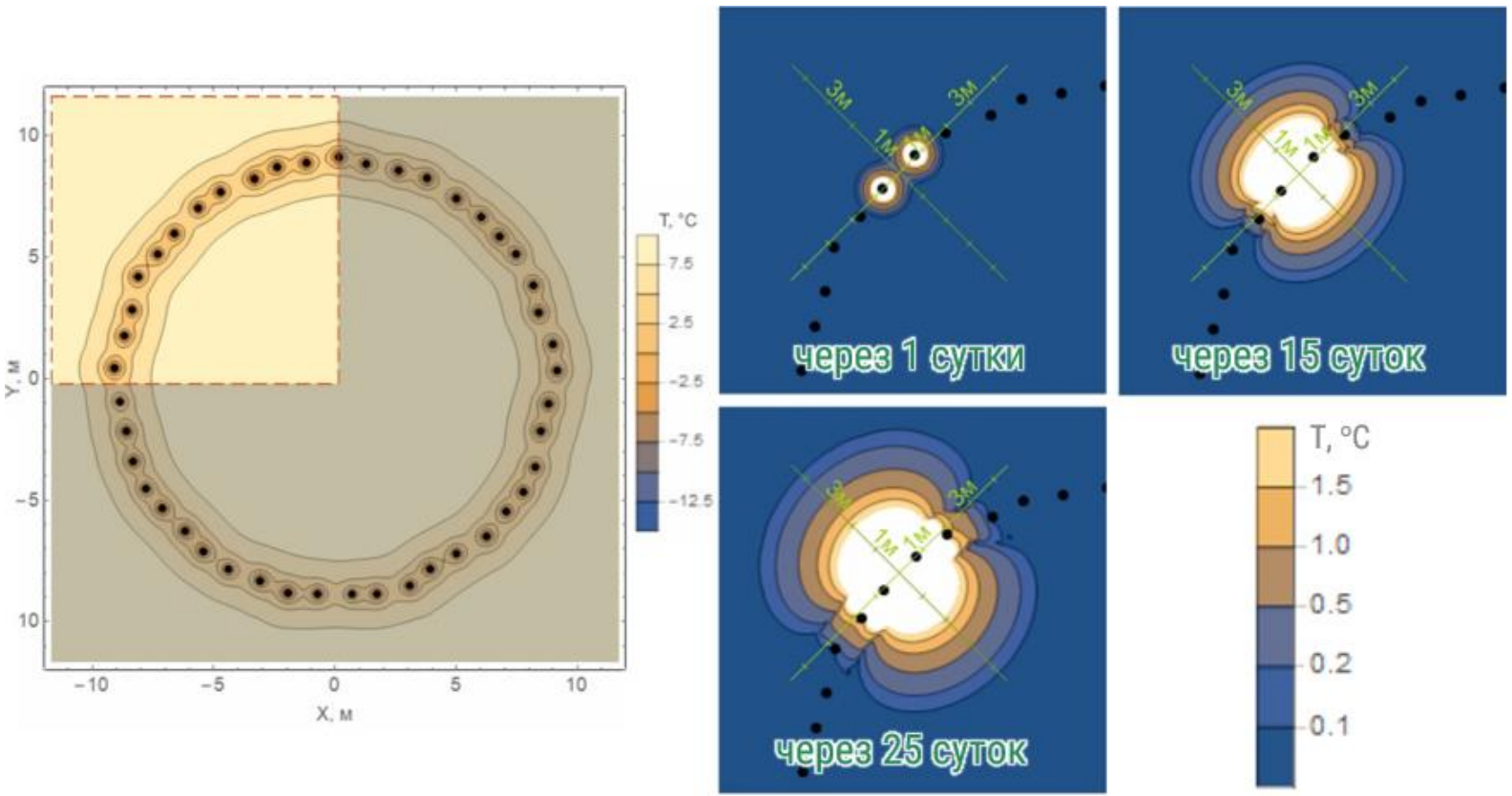

Рис. 7. Распределение температуры в исследуемом слое породы спустя 5 суток после начала его заморажсивания и рассогласования температурных полей при аварийном выходе колонок из строя

Fig. 7. Temperature distribution in the studied rock layer 5 days after the start of freezing and mismatch of temperature fields during an emergency freezing pipe failure

Точность измерений большинства приборов, с помощью которых определяется распределенная температура горных пород в термометрических скважинах, составляет $\pm 1,0^{\circ} \mathrm{C}$. Поэтому рассчитанные области с рассогласованием температуры, значение которой находится в пределах точности измерительных приборов, в реальных условиях не могут быть зафиксированы в окрестности скважин.

Из рис. 7 видно, что рассогласование температур более чем на $1,0^{\circ} \mathrm{C}$ через сутки после выхода из строя замораживающих колонок находится на их границе. Спустя 15 суток границы фиксируемой области рассогласования увеличиваются и находятся в среднем в радиусе 1,5 м от замораживающих скважин, через 25 суток - в радиусе 2,0 м. На основании анализа следует, что выявить аварийную ситуацию, связанную с выходом из строя замораживающих колонок, в начальный период ее развития не представляется возможным. При этом для того, чтобы обеспечить всесторонний контроль за состоянием ледопородного ограждения, количество контрольно-термических скважин должно быть значительным. Например, для рассматриваемого выше варианта, где замораживание породы вокруг шахтного ствола осуществлялось с применением 45 замораживающих скважин с расстоянием между ними равным $1,26 \mathrm{~m}$, требуется не менее $30 \%$ контрольно-термических скважин от общего количества замораживающих скважин, при этом достоверное рассогласование температур, вызванное аварией, возможно зафиксировать только через 15 суток.

Обоснование пространственного разрешения измерений распределенной температуры горных пород

Как правило, измерения температуры горных пород в контрольно-термических скважинах произво- дятся на уровне кровли и почвы каждого водоносного горизонта, однако, как показывают данные оптоволоконной термометрии, температура в интервале залегания даже одного горизонта может варьироваться в значительных пределах.

На рис. 8 представлено сравнение результатов экспериментальных измерений температуры породного массива в контрольно-термической скважине КТЗ шахтного ствола рудника Петриковского ГОК, которые получены при помощи оптоволоконного кабеля и локальных датчиков.

Сравнительный анализ результатов показывает, что ошибка определения фактической температуры может достигать $2,9^{\circ} \mathrm{C}$. В целях получения точных данных о тепловом поле замораживаемого участка породного массива, учитывая развитие технологии оптоволоконной термометрии, требуется решить вопрос о том, через какие минимальные интервалы необходимо и достаточно производить измерения температуры горных пород по глубине контрольнотермической скважины.

Для обоснования пространственного разрешения измерений температуры замораживаемых горных пород прежде всего следует использовать данные инженерно-геологических изысканий, включающих бурение вертикальных контрольно-стволовых скважин в местах расположения проектируемых выработок (геологическая колонка и описание керна). На основании полученных данных о бурении, включающих геологический разрез по оси каждого планируемого к строительству шахтного ствола, выделяются и объединяются близкие по составу и строению горные породы, слагающие породный массив.

Объединение горных пород в укрупненные литологические разности производится по теплофизиче- 
ским характеристикам (теплопроводность, теплоемкость, влагосодержание) при помощи соотношения:

$$
\Delta=\frac{\theta_{\max }-\theta_{\min }}{\theta_{\max }},
$$

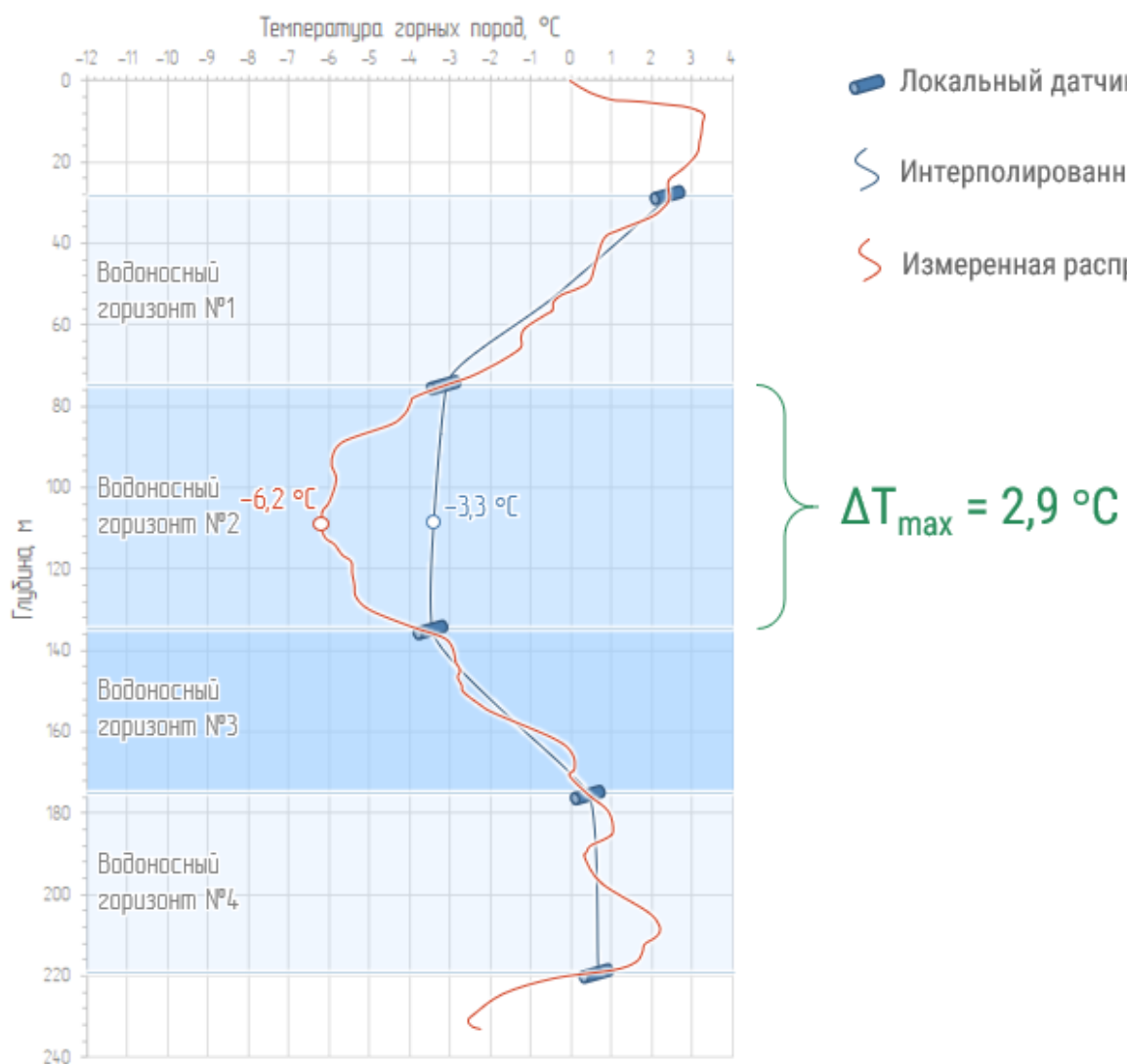

где $\theta_{\max }$ - максимальное значение теплофизической характеристики в выделенном слое горной породы; $\theta_{\text {min }}$ - минимальное значение теплофизической характеристики в выделенном слое горной породы.

Локальный датчик температуры

нтерполированное значение температуры

Измеренная распределенная температура

Рис. 8. Результаты экспериментальных измерений температуры породного массива в контрольно-термической скважине

Fig. 8. Results of experimental measurements of rock mass temperature in the control well

Следует отметить, что объединение слоев горных пород осуществляется таким образом, чтобы величина $\Delta$ в выделенном слое составляла не более $30 \%$. При этом, как показывает анализ динамики экспериментальных измерений температуры замораживаемого слоистого породного массива, значение мощности укрупненной литологической разности не должно составлять менее 2 м. Температура в маломощном слое в условиях его замораживания определяется температурой выше- или нижележащих более мощных литологических разностей, что объясняется влиянием вертикальных тепловых потоков через границы слоев.

В дальнейшем для получения детальной информации об изменении температуры по глубине каждой выделенной укрупненной литологической разности следует производить минимум три измерения. Два измерения должны выполняться на границах укрупненного слоя горных пород, и одно - по его середине. Таким образом, при мощности литологической разности, равной 2 м, и необходимости проведения в нем трех замеров температуры пространственное разрешение измерений распределенной температуры горных пород должно быть не более 1 м.
Методика определения оптимальных технологических параметров способа термометрического контроля

На основании проведенной статистической обработки экспериментальных измерений температуры замораживаемых горных пород и исследования влияния расположения термометрической скважины на точность решения обратной задачи Стефана получены следующие результаты по определению оптимального расположения контрольно-термических скважин на участке строительства шахтных стволов.

- Выбор мест заложения контрольно-термических скважин следует производить с учетом отклонений замораживающих скважин от проектного направления (идеально вертикального). Следовательно, бурение термометрических скважин должно производиться только после бурения замораживающих скважин и выполнения инклинометрических измерений.

- В целях точного определения проектных параметров ЛПО и времени их достижения контрольнотермическую скважину необходимо размещать на внешней границе ледопородного ограждения с его наибольшим расчетным значением требуемой толщины по всей глубине замораживания. При 
переходе на пассивный режим замораживания термометрия данной скважины позволит качественно управлять процессом искусственного замораживания посредством корректировки рабочих параметров холодильного оборудования.

- Расположение контрольно-термической скважины на внешней границе ЛПО с учетом допустимого отклонения от заданного направления скважин и неравномерного распространения замороженной зоны определяется по формуле:

$$
r_{E}=R_{3 \mathrm{C}}+k E_{\max }+\alpha_{\max 3 \mathrm{C}}+\alpha_{\text {perKT }}, \text { (7) }
$$

где $R_{3 \mathrm{C}}$ - проектный радиус контура замораживающих скважин, м; $k=0,4-$ установленный опытом коэффициент распространения замороженной зоны от контура замораживающих скважин в направлении от оси шахтного ствола; $E_{\max }$ наибольшее значение требуемой толщины ледопородного ограждения по глубине замораживаемого породного массива, м; $\alpha_{\max 3 c}-$ максимальное отклонение замораживающей скважины от вертикали в направлении от оси шахтного ство-

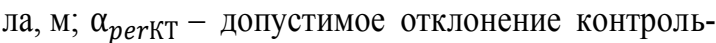
но-термической скважины от вертикали, м.

- Согласно терминологии, введенной в [1], зона замораживаемого массива с отрицательной температурой, где вода обращена в лед, называется 30ной льда, а остальная зона, в которой температура превышает температуру кристаллизации воды, зоной охлаждения. При решении задачи Стефана теплораспределение в рассматриваемой расчетной области обусловлено теплофизическими параметрами замораживаемой горной породы как в зоне льда, так и в зоне охлаждения, которые напрямую зависят от температуры. В связи с этим контрольно-термические скважины должны быть расположены не только в пределах ледопородного ограждения, но и за его внешними границами (границами движения фазового перехода). Для определения температуры горных пород в зоне охлаждения как показывает опыт, термометрическая скважина должна располагаться от проектной внешней границы ЛПО на расстоянии не менее чем 3 м, но не более $5 \mathrm{M}$.

- Для повышения надежности и точности определения температуры во всем объеме участка замораживаемого породного массива, учитывая влияние расположения термометрической скважины на точность решения обратной задачи Стефана, необходимо, чтобы контрольно-термическая скважина размещалась на прямой, проходящей посредине между двумя смежными замораживающими скважинами (замковая плоскость).

- По результатам термометрии контрольных скважин, расположенных в пределах границ ледопородного ограждения, можно производить оценку влияния параметров работы холодильного оборудования на замороженный породный массив и в случае необходимости корректировать их.
На основании результатов проведенных исследований с учетом анализа требуемого количества контрольно-термических скважин и обоснования пространственного разрешения измерений температуры горных пород разработана следующая методика определения оптимальных технологических параметров способа термометрического контроля состояния ледопородных ограждений.

1. По данным инклинометрических измерений, в пробуренных замораживающих скважинах определяется наибольшее расстояние по всему контуру их расположения и глубине бурения между двумя смежными скважинами. Середина наибольшей дуги окружности между замораживающими скважинами является местом заложения первой контрольно-термической скважины.

2. В соответствии с формулой (7) рассчитывается место заложения второй термометрической скважины.

3. Третья контрольно-термическая скважина должна быть расположена на участке замораживания горных пород за пределами ледопородного ограждения на удалении 3-5 м от внешней границы ледопородного ограждения.

4. Контрольно-термические скважины необходимо размещать на максимально возможном расстоянии друг от друга по периметру замораживаемого участка горных пород шахтного ствола.

5. В случае если проектная документация предусматривает проходку технологического отхода шахтного ствола до достижения проектных параметров ледопородным ограждением во всем интервале замораживания горных пород, требуется предусмотреть четвертую термометрическую скважину.

6. Пространственное разрешение измерений температуры горных пород в контрольно-термических скважинах шахтных стволов определяется на основе данных инженерно-геологических изысканий по формуле (6).

Отсюда следует, что для выполнения контроля за параметрами состояния ЛПО требуется три контрольно-термические скважины на участке замораживания строящегося шахтного ствола. На рис. 9 приведено схематичное представление мест заложения термометрических скважин, необходимых для контроля теплового поля замораживаемого породного массива.

При необходимости получения дополнительной информации о температуре породного массива целесообразность расположения дополнительных контрольно-термических скважин обосновывается проектом замораживания горных пород.

\section{Выводы}

Проведенные исследования, направленные на обоснование технологических параметров термометрического контроля ледопородного ограждения, позволяют сделать следующие выводы. 


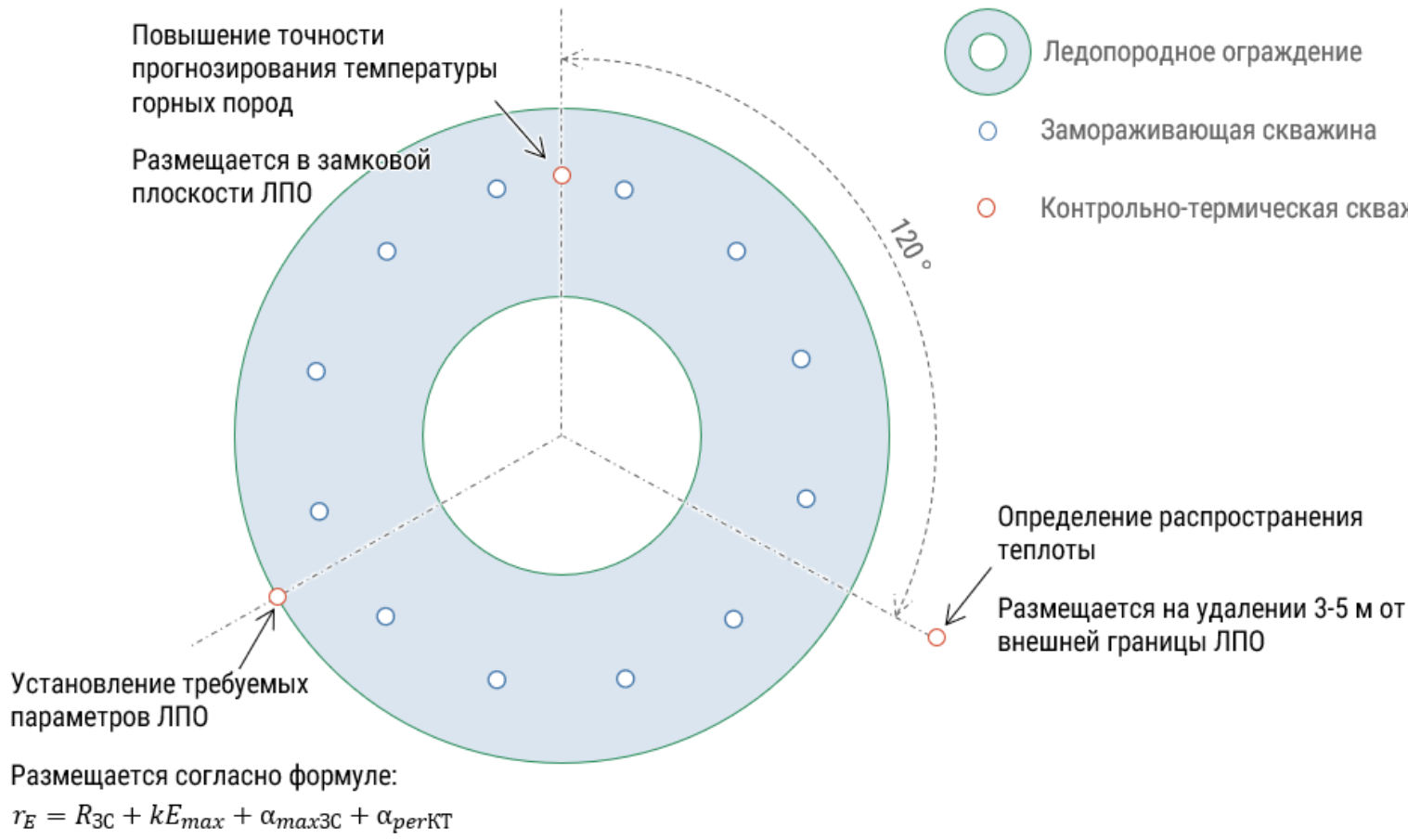

Рис. 9. Схематичное представление мест заложения контрольно-термических скважин

Fig. 9. Schematic representation of the location of the control thermal wells

1. Выявлены закономерности влияния процесса искусственного замораживания породного массива на его локальные участки.

2. Определено, что термометрическую скважину следует располагать в точке с наименьшей температурой на прямой, проходящей посредине между замораживающими скважинами.

3. Обеспечить всесторонний безаварийный контроль состояния ледопородного ограждения можно, только если количество контрольно-термических скважин составит не менее $30 \%$ от общего количества замораживающих скважин.

4. Экспериментальные измерения распределенной температуры горных пород в контрольно-

\section{СПИСОК ЛИТЕРАТУРЫ}

1. Трупак Н.Г. Замораживание пород при сооружении вертикальных стволов шахт. - М.: Недра, 1983. - 270 с.

2. Трупак Н.Г. Замораживание горных пород при проходке стволов. - М.: Углетехиздат, 1954. - 896 с.

3. Временное руководство по проектированию процесса замораживания пород для проходки вертикальных стволов шахт. Харьков: ВНИИОМШС, 1971. - 103 с

4. ВСН 189-78. Ведомственные строительные нормы. Инструкция по проектированию и производству работ по искусственному замораживанию грунтов при строительстве метрополитенов и тоннелей, утв. Приказом Главного технического управления Министерства транспортного строительства CСCP 10.05.1978. № 21. - 79 c.

5. ПБ 03-428-02. Правила безопасности при строительстве подземных сооружений, утв. постановлением Госгортехнадзора России 01.11.2001 г. № 49. - 167 с.

6. Правила технической безопасности при проходке стволов шахт специальными способами: утв. постановлением Министерства по чрезвычайным ситуациям Республики Беларусь 17.03.2004. № 5. 2004. - $14 \mathrm{c}$.

7. СП 103.13330.2012. Защита горных выработок от подземных и поверхностных вод, утв. приказом Министерства региональ- термических скважинах рекомендуется осуществлять с шагом не более 1 м по глубине замораживаемого массива пород.

Полученные результаты по определению оптимальных технологических параметров термометрического контроля ледопородного ограждения включены в Инструкцию по расчету параметров, контролю и управлению искусственным замораживанием горных пород при строительстве шахтных стволов на калийных рудниках ОАО «Беларуськалий».

Работа выполнена при финансовой поддержке Российского научного фонда в рамках научного проекта № 17-11-01204.

ного развития Российской Федерации (Минрегион России) 30.06 .2012 г. $-68 \mathrm{c}$

8. СП 45.13330.2012. Земляные сооружения, основания и фундаменты, утв. приказом Министерства регионального развития Российской Федерации (Минрегион России) 29.12.2011 г. $140 \mathrm{c}$.

9. Оптимизация процессов формирования ледопородного ограждения при сооружении шахтных стволов / Л.Ю. Левин, И.И. Головатый, Д.А. Диулин, О.С. Паршаков // Горный журнал. - 2018. - № 8. - С. 48-53. DOI: 10.17580/gzh.2018.08.06. URL: http://www.rudmet.ru/journal/1746/article/29905/?language=en (дата обращения 20.11.2019).

10. Левин Л.Ю., Семин М.А., Зайцев А.В. Решение обратной задачи Стефана при анализе замораживания грунтовых вод в породном массиве // Инженерно-физический журнал. - 2018. - Т. 91. № 3. - C. 655-663. DOI: 10.1007//10891-018-1782-3

11. Отчет о НИР «Проанализировать результаты теплофизических исследований образцов горных пород и обобщить данные для расчета и обоснования оптимальной толщины ледогрунтового ограждения при строительстве шахтных стволов способом замораживания на Нежинском (восточная часть) участке Старобинского месторождения калийных солей». Минск: Институт природопользования НАН Беларуси, 2013. $177 \mathrm{c}$ 
12. Отчет о НИР «Разработка исходных данных для проектирования скипового и клетевого шахтных стволов (научно методическое сопровождение при бурении скважин, лабораторные работы и исходные данные) Нежинского участка. Минск: ОАО «Белгорхимпром», 2014. - 235 с.

13. Отчет о выполненных работах «Проходка контрольностволовых скважин на шахтном поле рудника Талицкого ГОКа». - Пермь: ООО «Генезис-Пермь», 2011. - 504 с.

14. Отчет «Лабораторные исследования керна из контрольностволовых скважин на Талицком ГОКе». - Березники: ООО «Персил», 2011. - $51 \mathrm{c}$

15. Отчет о НИР № 58-12 «Разработка исходных данных для проекта проходки стволов Петриковского ГОК», в т.ч.: исходные данные по скиповому стволу». - Минск: ОАО «Белгорхимпром», 2013. - 192 c

16. Sopko J. Coupled heat transfer and groundwater flow models for ground freezing // ASCE GeoFlorida. - 2017. - V. 280. - P. 719-729.

17. Lewis R.W., Ravindran K. Finite element simulation of metal casting // International journal for numerical methods in engineering. - 2000. - V. 47. - № 1-3. - P. 29-59.

18. Modeling heat transfer between a freeze pipe and the surrounding ground during artificial ground freezing activities / M. Vitel, A. Rouabhi, M. Tijani, F. Guerin // Computers and Geotechnics. 2015. - V. 63. - P. 99-111.

19. Voller V.R., Swaminathan C.R., Thomas B.G. Fixed grid techniques for phase change problems: a review // International Journal for Numerical Methods in Engineering. - 1990. - V. 30. № 4. - P. 875-898.

20. Zhou M.M., Meschke G.A three-phase thermo-hydro-mechanica finite element model for freezing soils // International journal for numerical and analytical methods in geomechanics. - 2013. V. 37. - P. 3173-3193.

21. Левин Л.Ю., Семин М.А., Паршаков О.С. Совершенствование методов прогнозирования состояния ледопородного ограждения строящихся шахтных стволов с использованием распределенных измерений температуры в контрольных скважинах // Записки Горного института. - 2019. - Т. 237. - С. 268-274. DOI: 10.31897/PMI.2019.3.274

22. Алифанов О.М. Обратные задачи теплообмена. М.: Машиностроение, 1988. - 280 с.

23. Алифанов О.М., Артюхин Е.А., Ненарокомов А.В. Обратные задачи в исследовании сложного теплообмена. - М.: Янус-К, 2009. - 297 c

24. Ермаков С.М. Математическая теория планирования эксперимента. - М.: Наука, 1983. - 392 с.

25. Ермаков С.М., Жиглявский А.А. Математическая теория оптимального эксперимента. - М.: Наука, 1987. - 320 с.
26. Федоров В.В. Теория оптимального эксперимента (планирование регрессионных экспериментов). - М.: Наука, 1971. $312 \mathrm{c}$.

27. Inverse engineering handbook / Ed. by K.A. Woodbury. - Boca Raton: CRC press, 2002. - 466 p.

28. Fadale T.D., Nenarokomov A.V., Emery A.F. Two approaches to optimal sensor locations. // Journal of Heat Transfer. - 1995. V. 117. - № 2. - P. 373-379.

29. Karalashvili M., Marquardt W., Mhamdi A. Optimal experimental design for identification of transport coefficient models in convection-diffusion equations // Computers \& Chemical Engineering. - 2015. - V. 80. - P. 101-113.

30. Ucinski D. Optimal measurement methods for distributed parameter system identification. - Boca Raton: CRC Press, 2005. - $371 \mathrm{p}$

31. Амосов П.В., Лукичев С.В., Наговицын О.В. Влияние пористости породного массива и температуры хладоносителя на скорость создания сплошного ледопородного ограждения // Вестник Кольского научного центра РАН. - 2016. - № 4 (27). C. $43-50$.

32. Экспериментальные измерения температуры породного массива с использованием оптоволоконной технологии для анализа формирования ледопородного ограждения шахтных стволов / О.С. Паршаков, Л.Ю. Левин, О.А. Плехов, И.А. Пантелеев // Материалы XI Международного симпозиума по проблемам инженерного мерзлотоведения. - Магадан, 2017. C. $292-293$.

33. Пугин А.В. Исследование динамики тепловых полей при размораживании ледопородных ограждений строящихся стволов // Стратегия и процессы освоения георесурсов: сборник научных трудов. Вып.14. - Пермь: ГИ УрО РАН, 2018. С. $272-275$

34. Хайден Т.В., Вегнер Б. Современная технология замораживания пород на примере двух объектов, находящихся на стадии строительства, состоящих из пяти вертикальных шахтных стволов // Горный журнал. - 2014. - № 9. - С. 65-69.

35. Numerical simulation of artificial ground freezing in a fluidsaturated rock mass with account for filtration and mechanical processes / I.A. Panteleev, A.A. Kostina, O.A. Plekhov, L.Yu. Levin // Sciences in Cold and Arid Regions. - 2017. V. 9. - № 4. - P. 363-377.

36. Schmall P., Maishman D. Ground freezing a proven technology in mine shaft sinking // Tunneling \& Underground Construction. 2007. - V. 59. - № 6. - P. 25-30.

Поступила: 26.11.2019 2.

\section{Информация об авторах}

Семин М.A., кандидат технических наук, научный сотрудник отдела аэрологии и теплофизики, Горный институт Уральского отделения Российской академии наук, филиал Пермского федерального исследовательского центра Уральского отделения Российской академии наук.

Зайцев A.B., доктор технических наук, заведующий сектором математического моделирования и информационных технологий, Горный институт Уральского отделения Российской академии наук, филиал Пермского федерального исследовательского центра Уральского отделения Российской академии наук.

Паршаков О.С., младший научный сотрудник отдела аэрологии и теплофизики, Горный институт Уральского отделения Российской академии наук, филиал Пермского федерального исследовательского центра Уральского отделения Российской академии наук.

Желнин М.C., младший научный сотрудник лаборатории термомеханики твердых тел, Институт механики сплошных сред Уральского отделения Российской академии наук, филиал Пермского федерального исследовательского центра Уральского отделения Российской академии наук. 
UDC 622.253 .3

\title{
SUBSTANTIATION OF TECHNOLOGICAL PARAMETERS OF THERMAL CONTROL OF THE FROZEN WALL
}

\author{
Mikhail A. Semin 1 , \\ seminma@outlook.com
}

\author{
Artem V. Zaitsev 1 , \\ aerolog.artem@gmail.com
}

Oleg S. Parshakov ${ }^{1}$, olegprashakov@gmail.com

\author{
Maxim S. Zhelnin², \\ zhelninmax@gmail.com \\ 1 Mining Institute of the Ural Branch of the Russian Academy of Sciences, \\ 78-A, Sibirskaya street, Perm, 614007, Russia. \\ 2 Institute of Continuous Media Mechanics of the Ural Branch of the Russian Academy of Sciences, \\ 1, Academian Korolev street, Perm, 614013, Russia.
}

The relevance of the study is caused by the lack of regulatory documents for the control of the rock mass in the conditions of its artificial freezing, unified requirements for organization and monitoring of the frozen wall formation.

The main aim of the work is to substantiate the optimal technological parameters of the thermal control of the frozen wall.

Objects of the research are the rock mass under the conditions of artificial freezing and the freezing system.

Methods: experimental study of the temperature dynamics of the frozen rocks, statistical processing and analysis of experimental data; simulation of thermodynamic processes occurring in artificially frozen rock mass.

Results. The paper presents the experimental measurements of temperature distribution in control wells in artificially frozen rock mass. The artificial freezing is considered in relation to the problem of mine shaft sinking in flooded rocks. Processing and analysis of experimental data shown the influence of the artificial freezing on local sections of the rock mass. A study was made of the influence of the control well location on the accuracy of the solution of the inverse Stefan problem. It makes possible to adjust the thermophysical properties of the rock mass model and calculate the temperature field in the entire volume of the frozen rock mass. It was determined that the control well should be placed straight between the adjacent freezing wells. The analysis of the emergency failures of the freezing wells showed that the required number of control wells should be at least $30 \%$ of the total number of freezing wells. Performed thermal monitoring allows the substantiation of optimal locations and number of control wells with the necessary spatial resolution of temperature measurements of rock mass in depth. According to the results of the work, a methodology for selecting technological parameters of the method of frozen wall thermal control were proposed.

\section{Key words:}

Frozen wall, mine shaft, thermal control, technological parameters, thermal control well, temperature measurements, freezing well, Stefan problem.

The research was financially supported by the Russian Science Foundation within the scientific project no. 17-11-01204.

\section{REFERENCES}

1. Trupak N.G. Zamorazhivanie porod pri sooruzhenii vertikalnykh stvolov shakht [Freezing rocks during vertical mine shaft sinking] Moscow, Nedra Publ., 1983. 270 p.

2. Trupak N.G. Zamorazhivanie gornykh porod pri prokhodke stvolov [Freezing rocks in the case of shaft sinking]. Moscow, Ugletekhizdat Publ., 1954. $896 \mathrm{p}$.

3. Vremennoe rukovodstvo po proektirovaniyu protsessa zamorazhivaniya porod dlya prokhodki vertikalnykh stvolov shakht [Interim guidance on designing a process for freezing rocks for sinking vertical mine shafts]. Kharkiv, VNIIOMShS, 1971. 103 p.

4. VSN 189-78 Vedomstvennye stroitelnye normy. Instruktsiya po proektirovaniyu i proizvodstvu rabot po iskusstvennomu zamorazhivaniyu gruntov pri stroitelstve metropolitenov i tonneley, utv. Prikazom Glavnogo tekhnicheskogo upravleniya Ministerstva transportnogo stroitelstva SSSR [Departmental building codes. Instructions for the design and production of works on artificial freezing of soils during the construction of subways and tunnels, approved by order of the Main Technical Department of the Ministry of Transport Construction of the USSR] 10.05.1978. No. 21. $79 \mathrm{p}$.
5. PB 03-428-02 Pravila bezopasnosti pri stroitelstve podzemnykh sooruzheniy, utv. postanovleniem Gosgortekhnadzora Rossii [Safety rules for the construction of underground structures, approved by Resolution of the Gosgortekhnadzor of Russia]. 01.11.2001. No. 49. 167 p.

6. Pravila tekhnicheskoy bezopasnosti pri prokhodke stvolov shakht spetsialnymi sposobami: utv. postanovleniem Ministerstva po chrezvychaynym situatsiyam Respubliki Belarus [Technical safety rules for tunneling in special ways: approved by resolution of the Ministry of Emergency Situations of the Republic of Belarus]17.03.2004. № 5. 2004. $14 \mathrm{p}$.

7. SP 103.13330.2012 Zashchita gornykh vyrabotok ot podzemnykh $i$ poverkhnostnykh vod, utv. prikazom Ministerstva regionalnogo razvitiya Rossiyskoy Federatsii [Protection of mine workings from underground and surface waters, approved by the order of the Ministry of Regional Development of the Russian Federation]. 30.06.2012. $68 \mathrm{p}$.

8. SP 45.13330.2012 Zemlyanye sooruzheniya, osnovaniya i fundamenty, utv. prikazom Ministerstva regionalnogo razvitiya Rossiyskoj Federatsii [Earthworks and foundations, approved by the order of the Ministry of Regional Development of the Russian Federation]. 29.12.2011. $140 \mathrm{p}$. 
9. Levin L.Y., Golovatiy I.I., Diulin D.A., Parshakov O.S. Optimization of frozen wall formation in shaft construction. Gorny Zhurnal, 2018, no. 8, pp. 48-53. In Rus. DOI: 10.17580/gzh.2018.08.06. Available at: http://www.rudmet.ru/journal/1746/article/29905/ ?language $=$ en (accessed 20 November 2019).

10. Levin L.Yu., Semin M.A., Zaitsev A.V. Solution of an inverse Stefan problem in analyzing the freezing of groundwater in a rock mass. Journal of Engineering Physics and Thermophysics, 2018, vol. 91, no. 3, pp. 611-618. In Rus. DOI: 10.1007/s10891-018$1782-3$

11. Otchet o NIR.Proanalizirovat rezultaty teplofizicheskikh issledovaniy obraztsov gornykh porod $i$ obobshchit dannye dlya rascheta $i$ obosnovaniya optimalnoy tolshchiny ledogruntovogo ograzhdeniya pri stroitelstve shahtnykh stvolov sposobom zamorazhivaniya na Nezhinskom (vostochnaya chast) uchastke Starobinskogo mestorozhdeniya kaliynykh soley [Research report. Analyze the results of thermophysical studies of rock samples and summarize the data for calculating and justifying the optimal thickness of the frozen wall during the construction of mine shafts by freezing in the Nezhinsky (eastern part) section of the Starobinsky potassium salt deposit]. Minsk, Institute for Nature Management of the National Academy of Sciences of Belarus, 2013. 177 p

12. Otchet o NIR. Razrabotka iskhodnykh dannykh dlya proektirovaniya skipovogo $i$ kletevogo shakhtnykh stvolov (nauchno metodicheskoe soprovozhdenie pri burenii skvazhin, laboratornye raboty $i$ iskhodnye dannye Nezhinskogo uchastka) [Research report. Development of initial data for the design of skip and cage shaft shafts (scientific and methodological support when drilling wells, laboratory work and initial data) of the Nezhinsky site]. Minsk, Belgorkhimprom, 2014. 235 p.

13. Otchet o NIR. Prokhodka kontrolno stvolovykh skvazhin na shakhtnom pole rudnika Talitskogo GOKa [Research report. Drilling control wells in the mine field of the Talitsky mine]. Perm, PermGenesis Publ., 2011. 504 p.

14. Otchet o NIR. Laboratornye issledovaniya kerna iz kontrolno stvolovykh skvazhin na Talitskom GOKe [Research report. Laboratory tests of core from control wells at Talitsky GOK]. Berezniki, Persil Publ., 2011. 51 p.

15. Otchet o NIR. Razrabotka iskhodnykh dannykh dlya proekta prokhodki stvolov petrikovskogo gok $v$ tom chisle iskhodnye dannye po skipovomu stvolu [Research report. Development of initial data for the project of sinking the shafts of Petrikovsky GOK, including initial data on the skip shaft]. Minsk, Belgorkhimprom Publ., 2013. 192 p.

16. Sopko J. Coupled heat transfer and groundwater flow models for ground freezing. ASCE GeoFlorida, 2017, vol. 280, pp. 719-729.

17. Lewis R.W., Ravindran K. Finite element simulation of metal casting. International journal for numerical methods in engineering, 2000, vol. 47, no. 1-3, pp. 29-59.

18. Vitel M., Rouabhi A., Tijani M., Guerin F. Modeling heat transfer between a freeze pipe and the surrounding ground during artificial ground freezing activities. Computers and Geotechnics, 2015, vol. 63, pp. 99-111.

19. Voller V.R., Swaminathan C.R., Thomas B.G. Fixed grid techniques for phase change problems: a review. International Journal for Numerical Methods in Engineering, 1990, vol. 30, no. 4, pp. $875-898$

20. Zhou M.M., Meschke G.A three-phase thermo-hydro-mechanical finite element model for freezing soils. International journal for numerical and analytical methods in geomechanics, 2013, vol. 37, pp. 3173-3193.
21. Levin L.Y., Semin M.A. Parshakov O.S. Improving methods of frozen wall state prediction for mine shafts under construction using distributed temperature measurements in test wells. Journal of Mining Institute, 2019, vol. 237, pp. 268-274. In Rus. DOI: 10.31897/PMI.2019.3.274.

22. Alifanov O.M. Inverse heat transfer problems. Berlin, Heidelberg, Springer-Verlag, 1994. 348 p. Available at: https://www. springer.com/gp/book/9783642764387 (accessed 20 November 2019).

23. Alifanov O.M., Artyukhin E.A., Nenarokomov A.V. Obratnye zadachi $v$ issledovanii slozhnogo teploobmena [Inverse problems in the study of complex heat transfer]. Moscow, Janus-K Publ., 2009. $297 \mathrm{p}$

24. Ermakov S.M. Matematicheskaya teoriya planirovaniya eksperimenta [The mathematical theory of experimental design]. Moscow, Nauka Publ., 1983. 392 p.

25. Ermakov S.M., Zhiglyavskiy A.A. Matematicheskaya teoriya optimalnogo eksperimenta [The mathematical theory of an optimal experiment]. Moscow, Nauka Publ., 1987. 320 p.

26. Fedorov V.V. Teoriya optimalnogo eksperimenta (planirovanie regressionnykh eksperimentov) [The theory of optimal experiment (planning regression experiments)]. Moscow, Nauka Publ., 1971. $312 \mathrm{p}$.

27. Inverse engineering handbook. Ed. by K.A. Woodbury. Boca Raton, CRC press, 2002. $466 \mathrm{p}$

28. Fadale T.D., Nenarokomov A.V., Emery A.F. Two approaches to optimal sensor locations. Journal of Heat Transfer, 1995, vol. 117, no. 2, pp. 373-379.

29. Karalashvili M., Marquardt W., Mhamdi A. Optimal experimental design for identification of transport coefficient models in convection-diffusion equations. Computers \& Chemical Engineering, 2015, vol. 80, pp. 101-113.

30. Ucinski D. Optimal measurement methods for distributed parameter system identification. Boca Raton, CRC Press, 2005. 371 p.

31. Amosov P.V., Lukichev S.V., Nagovitsyn O.V. Influence of rock massif' porosity and coolant's temperature on velocity of solid ice wall creation. Herald of the Kola Science Centre of the RAS, 2016, vol. 4 (27), pp. 43-50. In Rus.

32. Parshakov O.S., Levin L.Yu., Plekhov O.A., Panteleev I.A. Experimental measuruments of rock mass temperature with the use of fiber-optic technology for analysis of ground freezing while shaft sinking. Book of abstracts. XI international symposium on permafrost. Magadan, 2017. pp. 292-293.

33. Pugin A.V. Issledovanie dinamiki teplovykh poley pri razmorazhivanii ledoporodnykh ograzhdeniy stroyashchikhsya stvolov [The study of the dynamics of thermal fields during the thawing of the frozen wall of constructed mine shafts]. Strategiya i protsessy osvoeniya georesursov: sbornik nauchnykh trudov. Vyp.14. Perm, GI UrO RAN, 2018. pp. 272-275.

34. Van Heyden T., Wegner B. Modern shaft freezing technology implemented in two big shaft sinking projects with total 5 surface mine shafts are being constructed. Gogny Zhurnal, 2014, no. 9, pp. 65-69.In Rus.

35. Panteleev I.A., Kostina A.A., Plekhov O.A., Levin L.Yu. Numerical simulation of artificial ground freezing in a fluid-saturated rock mass with account for filtration and mechanical processes. Sciences in Cold and Arid Regions, 2017, vol. 9, no. 4, pp. 363-377.

36. Schmall P., Maishman D. Ground freezing a proven technology in mine shaft sinking. Tunneling \& Underground Construction, 2007, vol. 59 , no. 6 , pp. $25-30$

Received: 26 November 2019.

\section{Information about the authors}

Mikhail A. Semin, Cand. Sc., researcher, Mining Institute of the Ural Branch of the Russian Academy of Sciences.

Artem V. Zaitsev, Dr. Sc., head of the sector, Mining Institute of the Ural Branch of the Russian Academy of Sciences.

Oleg S. Parshakov, junior researcher, Mining Institute of the Ural Branch of the Russian Academy of Sciences.

Maxim S. Zhelnin, junior researcher, Institute of Continuous Media Mechanics of the Ural Branch of the Russian Academy of Sciences. 